University of Nebraska - Lincoln

DigitalCommons@University of Nebraska - Lincoln

Faculty Publications from the Harold W. Manter Laboratory of Parasitology

7-1953

\title{
Studies on the Helminth Fauna of Alaska. XIII. Disease in the Sea Otter, with Special Reference to Helminth Parasites
}

Robert L. Rausch

Arctic Health Research Center (Anchorage, Alaska), rausch@u.washington.edu

Follow this and additional works at: https://digitalcommons.unl.edu/parasitologyfacpubs

Part of the Parasitology Commons

Rausch, Robert L., "Studies on the Helminth Fauna of Alaska. XIII. Disease in the Sea Otter, with Special Reference to Helminth Parasites" (1953). Faculty Publications from the Harold W. Manter Laboratory of Parasitology. 523.

https://digitalcommons.unl.edu/parasitologyfacpubs/523

This Article is brought to you for free and open access by the Parasitology, Harold W. Manter Laboratory of at DigitalCommons@University of Nebraska - Lincoln. It has been accepted for inclusion in Faculty Publications from the Harold W. Manter Laboratory of Parasitology by an authorized administrator of DigitalCommons@University of Nebraska - Lincoln. 
STUDIES ON THE HELMINTH FAUNA OF ALASKA. XIII. DISEASE IN THE SEA OTTER, WITH SPECIAL REFERENCE TO HELMINTH PARASITES

\author{
RoBert RAUSCH \\ Arctic Health Research Center, Public Health Service, Department of Health, Education, \\ and Welfare, Anchorage, Alaska
}

\section{INTRODUCTION}

During the spring of 1951 , the U. S. Fish and Wildlife Service undertook the removal of sea otter, Enhydra lutris (L)., from the Aleutian Island of Amchitka, for the purpose of restocking range from which the animals have long been exterminated. The decision to undertake this activity was influenced by the nature of military operations planned for the island later the same year. The capture and removal of the otter were under the supervision of Mr. Robert D. Jones, Biologist, U. S. Fish and Wildlife Service. Heavy losses among the animals shortly after capture made the venture unsuccessful. Many deaths were concurrent among animals in the wild state. The writer was asked to investigate the causes of disease in the sea otter, and it is the purpose of this paper to report the results of these investigations.

\section{Status of the Sea Otter}

The numerical recovery of the Aleutian sea otter populations has been very good in recent years, and some thousands of animals now occur in Alaskan waters. Their distribution, however, is discontinuous and much of their former range is unoccupied. This fact implies a slow rate of redistribution from the existing population centers. Sea otter are numerous around the islands comprising the Rat and Andreanof groups. The greatest known concentration is around the island of Amchitka, one of the Rat Islands.

Sea otter are likewise reduced in range and numbers in Asiatic waters. According to Bobrinskii et al. (1944 p. 134), they are still numerous around the Komandorskii Islands and Kamchatka (Cape Lopatka). On Mednii Island, in the Komandorskii group, otter are numerous, and here a comprehensive study of sea otter bionomics was made by BarabashNikiforov (1935). The report of Steller (1749) contains much important information on the biology and habits of the sea otter. His observations were made mainly on Bering Island. Sea otter reportedly still exist in the Kurile Islands, but the writer has no recent information regarding their status.

The characteristics of population behavior of the sea otter are little understood. Such knowledge would seem to permit some evaluation of the relationships of population density to morbidity, since it is evident that some of the disease conditions reported herein are directly related to utilization of invertebrate animals for food. Progress in this connection will be dependent upon carefullyplanned, long term investigations which utilize the best of modern techniques and trained personnel.

Amchitka-Characteristics of the Habitat

This work is concerned exclusively with sea otter disease on the island of Amchitka. Situated well toward the western end of the Aleutian Island chain, Amchitka is unique in being low and relatively flat. The maximum elevation, about 1300 feet, is attained in hills at the west end of the island. Boulder-strewn beaches, often bordered landward by steep or cliff-like banks, surround the island for the greater part. Sandy beaches are few. Rock outcroppings jut into the sea and form precipitous cliffs. 
The shore is broken by fjord-like clefts. Rocky flats are exposed at low tide, and these serve as the feeding and resting places of great numbers of waterfowl.

Numerous invertebrate animals occur in the tide pools and just outside the tidal zone. Conspicuous forms are Mytilus edulis L., Littorina atkana Dall, Acmaea digitalis Eschscholtz, Katherina tunicata Wood, and Strongylocentrotus dröbachiensis (Müller). Marine algae grow luxuriantly around the island, with Alaria, Nereocystis, and Fucus most plentiful. Fishes are abundant, and one of the most common forms, according to collecting results, is a greenling, Lebius superciliosus (Pallas). Various species of sculpins (Cottidae) are also numerous.

Great quantities of algae and animal remains are deposited by the sea in windrows well up on the shores. Such debris may extend into the zone grown to rye grass, Elymus arenarius mollis (Trin.) Hult., which usually covers the banks and certain other areas, such as sites of old Aleut habitations. Rats, Rattus norvegicus Berkenhout, and arctic foxes, Alopex lagopus L., both introduced by man, forage among this debris. The banks are much tunneled by the rats, and the description by Schiller (1952) of conditions existing on Adak Island applies well here. Hundreds of sea birds, particularly alcids, nest on offshore rocks. Landnesting birds, formerly abundant, have been much reduced, apparently through the depredations of rats and foxes-another example of the results of introducing exotics without thought of the consequences. Pinnipeds are numerous. The harbor seal, Phoca vitulina L., is the most abundant, and Steller's sea lion, Eumatopias jubata (Schreber), is locally common. These animals are found in the same localities as the sea otter and in some places use the same haulinggrounds.

An estimate of three to four thousand sea otter on Amchitka may not be unreasonable, although the actual number is not known. Otter appear to be distributed around the entire island, but not uniformly so. Some aggregations of otter are relatively large, and it appears that, for much of the year, these retain their identity. Thus, a group of about 130 otter was regularly observed a few miles west of Kirilof Bay in the spring of both 1951 and 1952. Observations made both earlier and later by other workers indicated no change in this behavior. Little is known, however, of summer and fall activity. Besides such obvious concentrations of animals, smaller groups and single individuals may be seen at any time along the shores of Amchitka.

The feeding habits of sea otter have been the subject of considerable study. The report of O. J. Murie (1940) includes information on diet composition and other phases of the bionomics of this animal. Jones (1951) has presented general information on the Amchitka sea otter. Details on the diet need not be discussed in this paper, except where pertinent to the following consideration of parasite life cycles.

\section{ACKNowledgments}

The writer wishes to express appreciation of aid rendered in connection with this work by the following: Messrs. Robert D. Jones, Paul Adams, Russell R. Hoffman, W. K. Clark, and David Hooper, biologists with the U. S. Fish and Wildlife Service, assisted in various ways with the field work on Amchitka; Mr. E. L. Schiller, of this laboratory, studied the nematode material collected; Miss Reggie V. Sacressen, of this laboratory, prepared the histological sections and drawings of $M$. pirum. Thanks are also expressed to Dr. Rue Jensen, Colorado A. and M. College, for reviewing certain slides, and to Miss Thirza Donnegan, Alaska Department of Health, for the evaluation of hematological material.

The U. S. Fish and Wildlife Service supported the cost of the field work on 
Amchitka. Without this cooperation, the work would not have been possible.

\section{Materials and Methods}

Three animals were examined by the writer in 1949. Losses were relatively light this year, and the animals, having been found dead on the beach, were not in suitable condition for study. In 1949 no particular significance was attached to the few deaths known to have occurred on Amchitka.

No losses were reported in 1950 . Heavy losses, however, occurred in February, 1951, and continued through this month and early March. The writer arrived on Amchitka March 19, 1951. Dead otter were still numerous, but by this time numerous deaths were no longer occurring. On March 19, the writer observed 14 dead otter along a two-mile stretch of beach. These animals were in such condition as to be of little value for detailed examination. Many dead animals were examined, but only 19 were obtained in acceptable condition.

During March, 1952, the writer spent ten days on Amchitka. Fish and Wildlife Service personnel had been there some weeks prior to this time, and it was agreed that only light losses had occurred during late winter, 1952. Eight animals in suitable condition for study were obtained. Mr. David Hooper, U. S. Fish and Wildlife Service, examined a few more after the writer's departure. Mr. E. L. Schiller, of this laboratory, continued observations in May and June, 1952, but noted only a few remnants of sea otter carcasses, believed to be animals which had died during the previous winter or early spring.

Most of the data included herewith were obtained by the writer through the post mortem examination of sea otter in the field, together with later laboratory study of materials collected. As is noted, it was not possible to obtain an adequate number of otter in condition suitable for study. Because of the strict regulations governing the slaughter of the animals, normal otter could not be utilized in connection with this investigation.

Morbid animals were occasionally found on the beaches, where they could be readily captured. Other animals, considered normal when captured, became morbid in captivity. In either case, death of the animal was the final outcome. It is not possible at this time to evaluate the effect handling, artificial food, and confinement might have on the captive otter. There is some indication that captivity has an adverse effect, but further investigation is required.

All captured otter were confined in wire enclosures around fresh-water tundra ponds, or in cages. Captive animals were observed closely in order to record clinical symptoms of diseases affecting them. Because of the diversity of conditions present, such observations had little value.

Almost all of the sea otter obtained during the course of this work were subadults. Twenty-eight ranged in weight from 3.7 to $73 \mathrm{lbs}$. The average weight was $34 \mathrm{lbs}$. Four animals were considered normal; these were a cub (3.7 lbs.), a large male (73 lbs.), and two females (51 and 33 lbs.). Besides these, only two more females were obtained. The heaviest mortality occurred, on the basis of this, in subadult males. An abnormal sex ratio was evident.

Animals dying in captivity were autopsied as soon as possible after death. Several otter found dying upon the beaches, as well as captive animals in the terminal stages of disease, were killed to obtain material more suitable for study. Detailed examination of such animals was made in the field, and appropriate tissue specimens were collected for later histopathological study. Inoculations of bacteriological media were made from various organs at the time of autopsy. Preliminary incubation of this material was carried out on Amchitka, but all further work was completed in the laboratory at 
Anchorage. Blood smears were made routinely from the living animals, and blood serum was collected whenever possible.

Tissues for histopathological study, after fixation in either formalin-acetic acid-alcohol or ten per cent formalin, were embedded by the paraffin method. Sections were stained routinely with hematoxylin-eosin and Mallory's aniline blue stain. Heidenhain's azan stain, Turnbull's blue method for hemosiderin, LeeBrown's modification of Mallory's aniline blue stain, Unna's differential stain for mast and plasma cells, and Mallory's fuchsin stain for hemofuscin, were applied in special cases. Trematodes were stained in Ehrlich's acid hematoxylin or Semichon's acetic carmine stains. The nematodes were cleared for study in licuefied phenol.

\section{Results}

The present investigation has revealed that the sea otter is subject to infection by a variety of helminth parasites. These affect the host to varying degrees-most appear to have little significance, but at least two are highly pathogenic. Ante mortem diagnosis of disease in sea otter will have to depend on the results of further, more intensive study. All parasites recorded from sea otter during this investigation are considered separately in some detail. In connection with certain of these parasites, appropriate remarks on taxonomy and morphology have been included. Details on helminth species occurence have been summarized for 31 animals. Other pertinent data are included.

\section{Pyramicocephalus phocarum} (Fabricius, 1780)

Found but once in a $73 \mathrm{lb}$. adult otter, $P$. phocarum appears to be of rare occurrence in this host species. The specimen collected was only $58 \mathrm{~mm}$. long, and sexually immature. Nothing could be observed regarding localization of this cestode in the host, since circumstances delayed for some time after death the examination of this animal. Upon autopsy it was found that all parasites present had relinquished any attachment to the host tissue. No gastric or intestinal lesion characteristic of the attachment of $P$. phocarum in other hosts was observed.

The writer had collected this species of cestode rather frequently from the bearded sea 1, Erignathus barbatus (Erxleben), along the Arctic Coast of Alaska. In the bearded seal, P. phocarum attaches itself to the muscosa of the pyloric region of the stomach. The highly specialized scolex is always deeply embedded in the tissue of the host, so that the cestode is pulled away only with difficulty. A crater-like lesion about 5 $\mathrm{mm}$. in diameter is characteristically seen at the place of attachment. A mild tissue reaction occurs.

Barabash-Nikiforov (1935) recorded an unidentified cestode from Bering Island sea otter. Afanas'ev (1941) reported no cestodes from animals examined by him.

\section{Orthosplanchnus fraterculus Odhner, 1905}

The most common parasite collected, O. fraterculus occurred in 28 of 31 otter examined. Nothing is known of the life cycle of this trematode, but it was concluded that otter regularly become infected during their first year of life.

The writer has observed $O$. fraterculus in both the gall bladder and pancreatic ducts of the bearded seal, but in the sea otter it appears to be limited in locus to the gall bladder. The sea otter gall bladder is somewhat specialized, and a few appropriate remarks regarding its structure are included herewith:

In the adult male otter, the gall bladder attains a maximum length of about $150 \mathrm{~mm}$. It is elongate, with gradual enlargement toward the distal end ; the maximum diameter is about $20 \mathrm{~mm}$. Observations indicate that the sea otter gall 
bladder is not capable of much contraction or expansion. The walls of the organ are relatively very thick. The muscular layer with the perimusclar connective tissue has a thickness of at least 4 $\mathrm{mm}$. in the adult animals. This thickness is about equaled by that of the combined mucosa and lamina propria. The mucosa has many gland-like openings throughout, but the epithelium lining the majority of these is not glandular. According to staining results, it is possible that a few glands do occur in the mucosa of the body of the organ, but this needs further study. The relatively small quantity of bile observed in all animals examined by the writer has been somewhat viscous, with a slightly greyish or greenish tinge. The usually dark green color characteristic of bile has not been observed.

Gross pathological changes. Incision of the gall bladder disclosed the organ in most cases to be filled almost completely by hundreds of trematodes. These attach themselves firmly to the mucosa, with the posterior end projecting into the lumen. Fibrotic nodules of various sizes up to about $2 \mathrm{~mm}$. were noted. Chronic infections, in old animals, resulted in extensive fibrosis. Fibrocytic proliferation may bring about occlusion of the gall bladder lumen. This would seem to be further evidence that the organ changes its state of contraction very little.

Histopathological observation. Transverse sections of the gall bladder showed that the trematodes attach themselves by taking into the oral and ventral suckers a considerable quantity of host tissue. $O$. fraterculus has an integument armed with sharp spines about $16 \mu$ long. These spines cause chronic irritation of the mucosa, with the resulting above mentioned fibrosis (Fig 1.). Mucosa hypertrophy may also be characteristic of $O$. fraterculus infections. Adequate material from non-infected otter for comparison was not available to permit a decision on this point. Trematode eggs were often seen entrapped by the host tissue reaction (Fig. 2). Mononuclear cells infiltrated immediate areas surrounding the trematodes, and also the eroded superficial layers of mucosa. Hyperemia was never marked.

Pathogenicity. While O. fraterculus is mildly pathogenic, there is no evidence suggesting an important effect on the host. The occlusion of the lumen of the gall bladder does not appear to bring about serious changes. Accumulation of bile distal to the occluded portion was not observed. No tendency toward occlusion of the cystic duct was noted.

\section{Phocitrema fusiforme Goto and Ozaki, 1930}

As a parasite of the sea otter, $P$. fusiforme seems to have no importance. The writer has collected it but once from otter, but it occurs frequently in Aleutian Island foxes. A second record of this trematode from the sea otter was obtained by Mr. David Hooper, U. S. Fish and Wildlife Service, during late March, 1952. The animal examined by him was very young, weighing only $12 \mathrm{lbs}$., and was still in company of an adult female. In addition to Amchitka foxes, two foxes from the island of Kiska were found to harbor $P$. fusiforme. Afanas'ev (1941) recorded this trematode from the fur seal, Callorhimus ursinus L., in the Komandorskii Islands.

\section{Pricetrema zalophi} (Price, 1932)

Of rare occurrence in the sea otter, $P$. zalophi has no apparent effect upon the host. This minute trematode was recorded but once by the writer from Amchitka sea otter, and it was not collected from any other host species. The life cycle of $P$. zalophi is unknown.

V. Microphallus pirum (Afanas'ev, 1941)

(Syn. Paraheterophyes pirum Afanas'ev, 1941 ; Microphallus enhydrae Rausch and Locker, 1951.) 


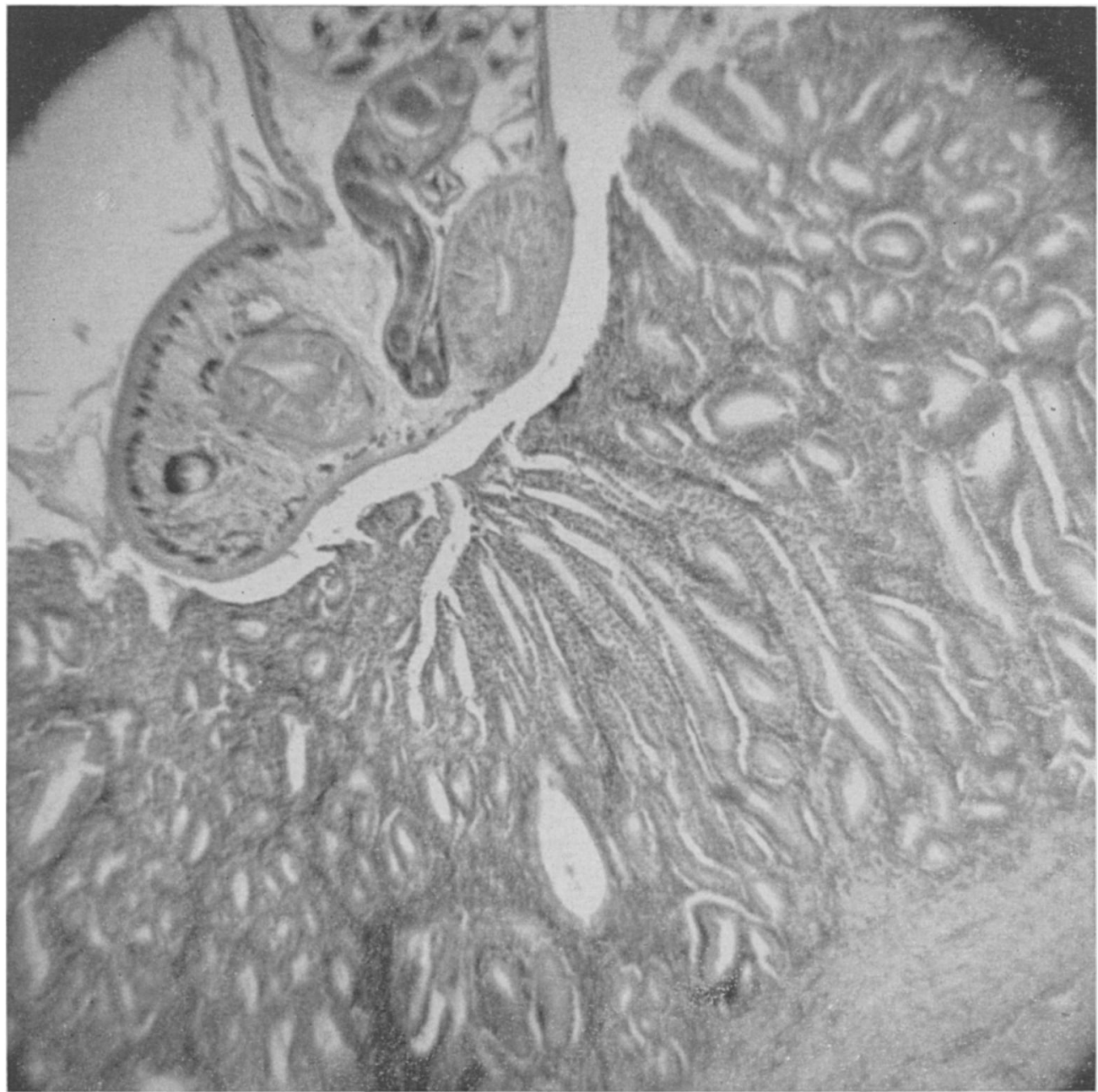

FIG. 1. Transverse section of sea otter gall bladder with specimen of Orthosplanchnus fraterculus in situ. Low power.

First recorded from the intestine of sea otter and arctic foxes on Bering and Mednii Islands (Afanas'ev 1941), $M$. pirum is a common and important parasite of sea otter on Amchitka. It was collected from 21 of 31 animals studied in detail.

Without knowledge of Afanas'ev's paper, this trematode was described by Rausch and Locker (1951) as Microphallus enhydrae. Dr. James E. Lynch, School of Fisheries, University of Washington, called to the writer's attention the report of Afanas'ev. Some discussion of the taxonomic status of the trematode is pertinent here.

A new genus, Paraheterophyes, was erected by Afanas'ev (1941) for the single species, $P$. pirum. Among related genera Paraheterophyes was differentiated only from Heterophyes Cobbold, 1866. Afanas'ev stated (p. 97) that “ . . . it differs from this genus in having a different arrangement of the uterus, of the testes, vesicula seminalis, and in several other characters." The genus Microphallus Ward, 1901, was not considered, al- 


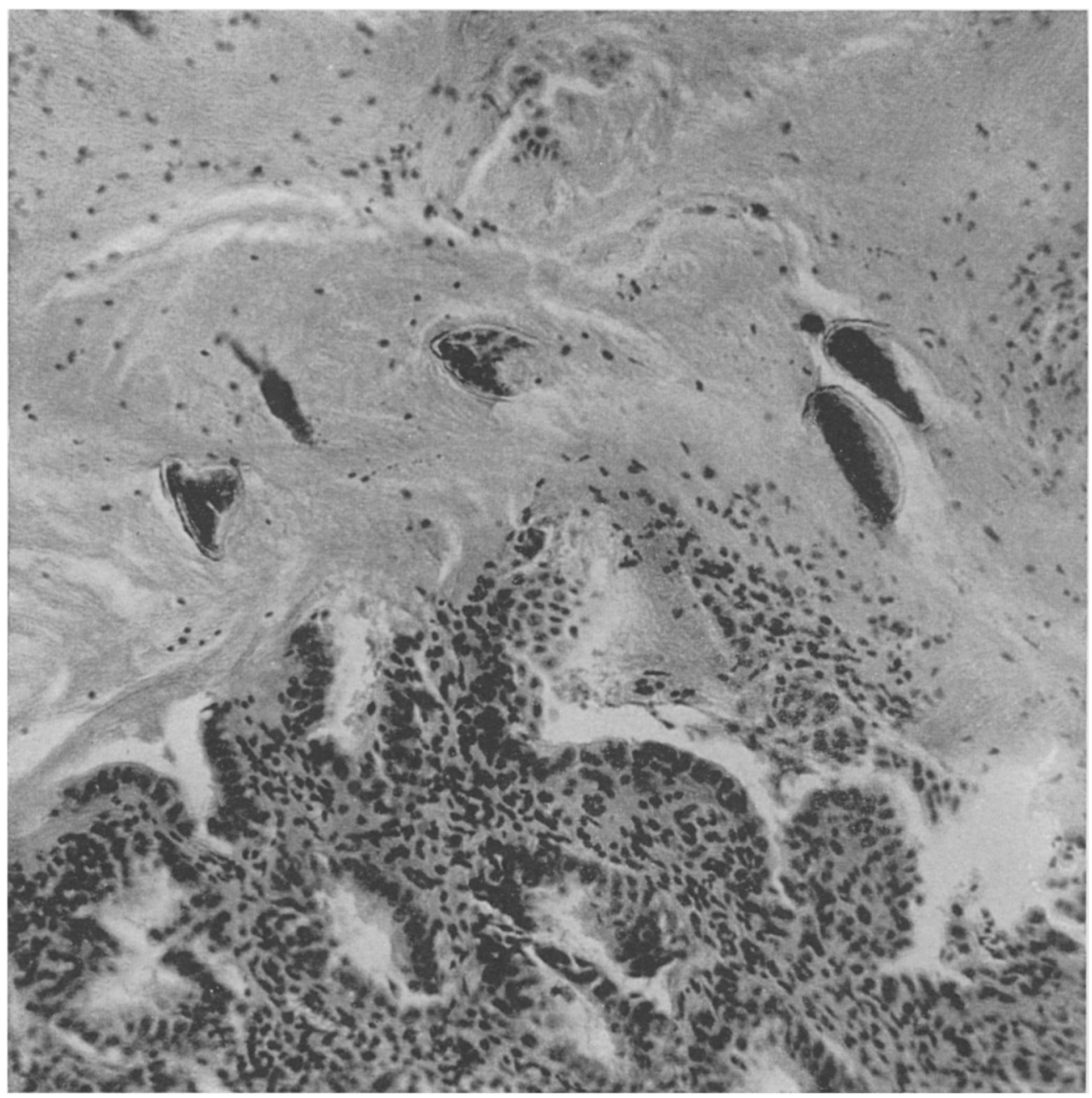

FIG. 2. Sea otter gall bladder showing fibrosis and entrapped eggs of Orthosplanchnus fraterculus. High power.

though, in the writer's opinion, Afanas'ev's species clearly belongs here.

The original Aleutian material was obtained by the writer from otter found dead upon the Amchitka beaches and subsequently stored for some weeks in a frozen state. The trematodes had degenerated, and this gave rise to certain inaccurate interpretations of morphological details. The later opportunity for the collection of living worms provided an abundance of material in condition for study. Serial sections of the trematodes in situ were also prepared. A drawing of an entire specimen of $M$. pirum, and details of the genital ducts, are included (Figs. 3-5).

The study of this additional material has disclosed nothing which would invalidate its assignment to Microphallus. It should be pointed out that the cuticle of $M$. pirum is, as described by Afanas'ev, thickly beset with spines. The Komandorskii Island specimens averaged somewhat larger than those from Amchitka, but rather remarkable size variation in the species of Microphallus appears to be the rule (Rausch 1947). 


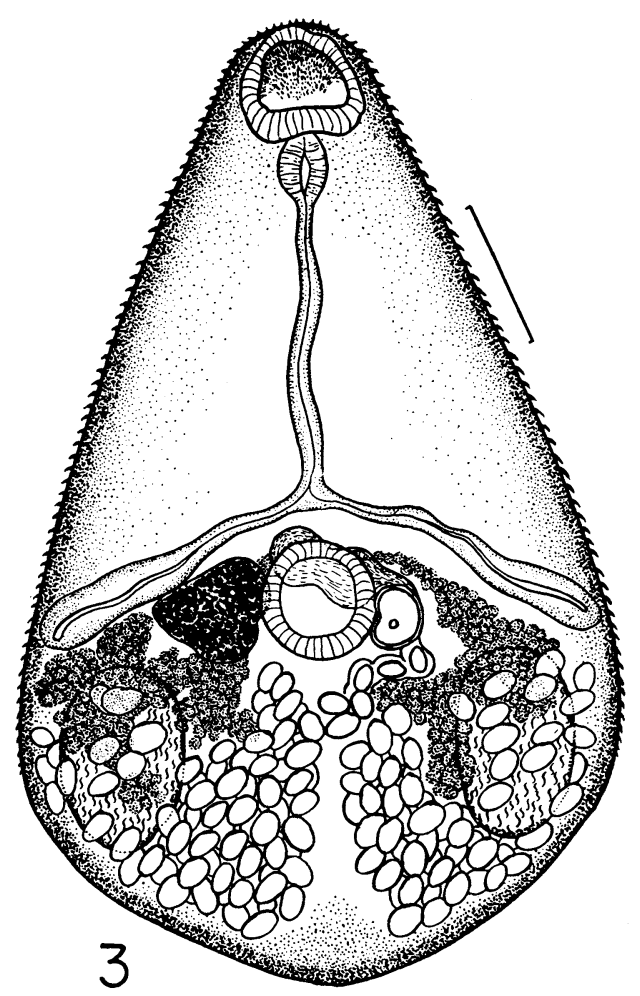

FIG. 3. Microphallus pirum, entire specimen, ventral view; from sea otter intestine. Scale has a value of $60 \mu$.

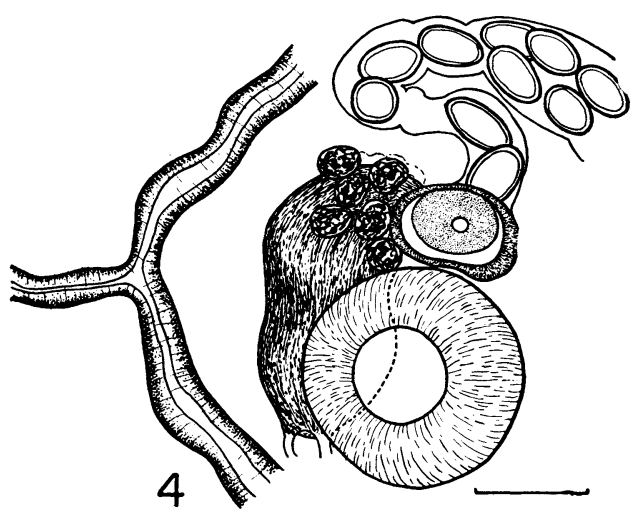

FIG. 4. Enlargement of terminal portions of genital ducts of Microphallus pirum. Scale has value of $30 \mu$.

The recent papers by Cable and Kuns (1951) and by Stunkard (1951) did not consider $M$. pirum in any detail; these workers also were apparently unaware of Afanas'ev's publication.

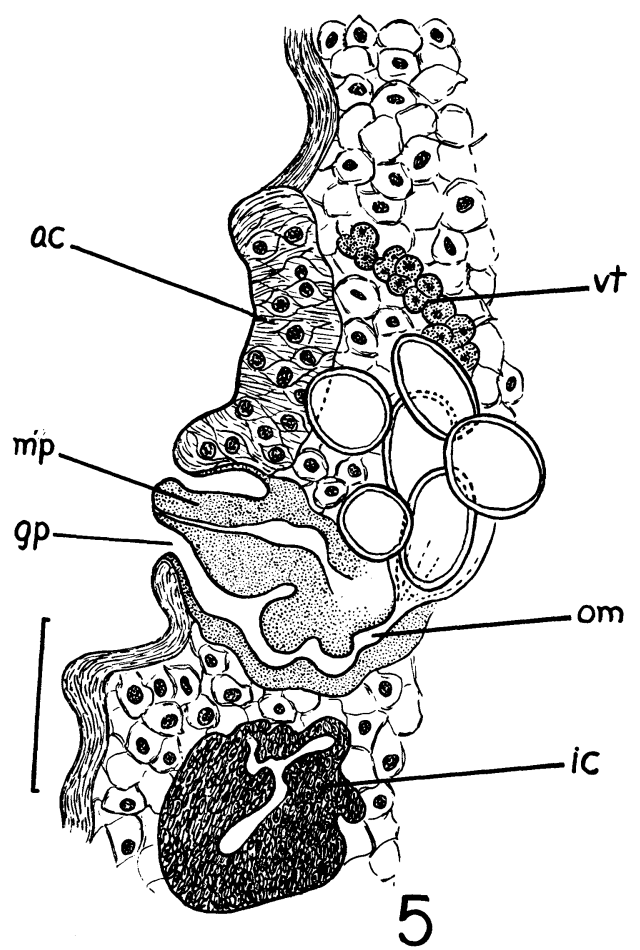

FIG. 5. Oblique section through acetabulum and genital pore of Microphallus pirum. ACacetabulum; MP-copulatory papilla; GPgenital pore; VT-vitelline gland; OM-end of metraterm; IC-intestinal cecum. Scale has value of $30 \mu$.

The entire life cycle of $M$. pirum is unknown. Afanas'ev assumed some species of fish to be the second intermediate host, but the writer thought it to be a crab. The writer was unsuccessful in the collection of crabs on Amchitka; however, Mr. E. L. Schiller, of this laboratory, during May and June, 1952, collected a series of hermit crabs from tide pools. These he found to be infected by the metacercarial stage of $M$. pirum. Schiller (1953) has reported his work separately.

$M$. pirum is no doubt pathogenic, but its true effect on the sea otter host may have been in part obscured by the presence of another pathogen. Consequently, the following descriptions are written with the realization that some of the pathological changes observed may not be attributable to $M$. pirum alone. 
Gross pathological changes. An enteritis of varying degrees of severity was observed in every case with the presence of moderate to great numbers of trematodes. Semi-fluid excreta containing a large proportion of blood were characteristic. Post mortem examination of such animals disclosed marked hyperemia of the villi, and the dark brown to blackish color of the intestinal content indicated much extravasation of blood. Gastritis, relatively mild, was noted in the majority of cases. In particularly severe cases of enteritis, exudate containing much fibrin was closely adherent to the mucosal surface. The trematodes, occurring only in the small intestine of the host, were distributed through the layer of exudate which adhered to the mucosal surface. They occurred also in the exudate in the lumen, but were relatively fewer here. The trematodes appeared as minute, dark bodies on the mucosal surface; the dark-colored eggs in the voluminous uterus of $M$. pirum alone being visible, since the remainder of the worm's body is transparent. (The trematode body averages less than $500 \mu$ in length.) A maximum number of 30 trematodes per square $\mathrm{mm}$. of mucosal surface was counted (in a cleared gross-section of intestine).

Histopathological observations. Severe mucosal hyperemia was characteristic, as was extensive desquamation of mucosal epithelium. Trematodes occurred at all levels in the intestinal wall (Fig. 6 ). The greatest numbers occurred in the mucosa, but some had penetrated the muscularis externa. Complete intestinal perforation was observed, with trematodes localized on the serosal surface. In such cases a slight inflammatory reaction had been evoked, with fibrocytic proliferation and invasion by mononuclear leukocytes. Polymorphonuclear neutrophils were absent. Within the intestinal wall, fibrosis around the trematodes was not noted. There was also little or no leukocytic infiltration, indi- cating that the trematodes were actively migrating through the tissue. This impression was further supported by evidence of mechanical damage to the mucosa. Trematodes were fewer, and were more superficially localized, in the lower part of the small intestine. Bacteria were not much in evidence anywhere, and were not seen invading the living tissue along with the trematodes. Trematode eggs were not observed in the intestinal tissue. No lesions in other organs were noted which could be attributed to $M$. pirum infection.

Pathogenicity. On the basis of mechanical damage alone, brought about by the movements of the trematodes, it would appear that $M$. pirum has an important pathogenic action. The cuticle of $M$. pirum is beset with great numbers of recurved spines which must contribute much to the irritation of the host tissue. If the observations have been correctly interpreted, it would seem that the degree of pathogenicity is directly proportional to the number of trematodes present. Trematodes of all ages, including newly ingested, but excysted, metacercariae, were regularly seen in a single animal, indication that there may be a constant increase in number.

$M$. pirum appears to behave much as various species of heterophyid trematodes in that extensive mucosal invasion takes place before maturity, but the parasites return after maturing to the intestinal lumen. This concept is supported by the lack of eggs in the host tissue. In cases where trematodes are localized permanently deep within the host tissue, free eggs entrapped by the tissue reaction of the host are usually observed. Willey and Stunkard (1942) reviewed the tissueinvasion behavior of various heterophyid species in the definitive host, and also investigated fully the life cycle and pathogenicity of a heterophyid trematode, Cryptocotyle lingua (Creplin 1825). They reported heavy losses caused by $C$. lingua among young foxes. These workers 


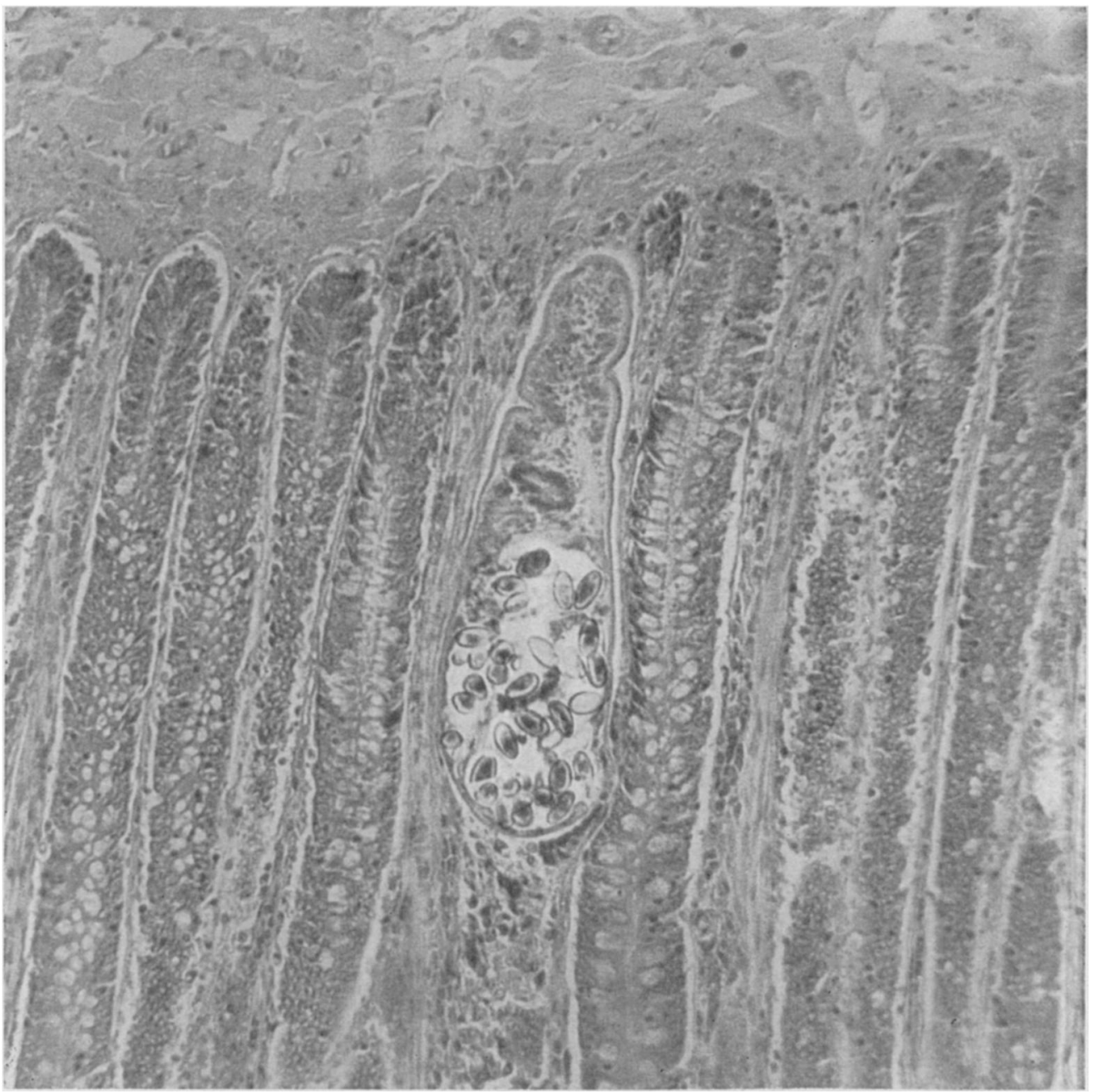

Fig. 6. Specimen of Microphallus pirum in mucosa of sea otter intestine. Low power.

were able to produce fatal experimental infections of large adults dogs by feeding fishes harboring the metacercarial stage of C. lingua. They summarized the effect of the parasites on the dog intestine as follows: "They denude the epithelium, produce a copious exudation of mucus, cause pressure atrophy, necrosis, sloughing of tissue, 'hyperemia, infiltration of eosinophils and plasma cells, and hyperplasia of the fixed tissue elements. The damage is largely mechanical and limited to the surface of the villi and the region between them." If anything, the effect of $M$. pirum on the sea otter is more severe, since the degree of tissue invasion is much greater.

The writer has no evidence that the eggs of $M$. pirum are ever distributed by the bloodstream of the host, with resulting serious effect, as was described by Africa et al. (1935), for certain heterophyid trematodes (Monorchotrema taichui Nishigori, 1924; M. taihokui Nishigori, 1924; Diorchotrema pseudocirrata Witenberg, 1929; Heterophyes breviceca Africa and Garcia, 1925). These trematodes invade the intestinal mucosa of man or other mammals.

Cordy and Gorham (1950) studied the 
effect of Troglotrema salmincola (Chapin, 1926) on the host intestine. The pathological changes brought about by the trematodes per se resembled in general those observed in $M$. pirum infections, although not so severe.

Afanas'ev (1941) recorded also Nanophyetus sp. (= Troglotrema sp.) from Komandorskii sea otter. This species was not recorded from Aleutian animals.

\section{Porrocaecum decipiens}

(Krabbe, 1878)

During the present investigation but one species of nematode, Porrocaecum decipiens, was recorded from Aleutian Island sea otter. It has been reported from the same host by Barabash-Nikiforov (1935) and Afanas'ev (1941), in the Komandorskii Islands. A larval specimen of Porrocaecum sp. was collected by $\mathrm{O}$. J. Murie (Murie et al.; ms.) from an otter taken on Ogliuga Island.

The name Porrocaecum decipiens is applied here, although its validity is somewhat controversial. A discussion of the nomenclatorial status of this nematode has been presented by Johnston and Mawson (1945, pp. 110-116). A detailed description of Ascaris decipiens (=P. decipiens) was published by Stiles and Hassall (1899, pp. 109-120). These workers also summarized from the literature a list of mammals from which $P$. decipiens has been recorded.

The life cycle of $P$. decipiens has been investigated by several workers. Various species of fish serve as the intermediate host. Around Amchitka, according to the observations of E. L. Schiller, a greenling, Lebius supercilosus (Pallas), often harbors the larvae of $P$. decipiens. Other species are no doubt also infected here. The writer has observed sea otter at the surface with still-living greenlings, upon which they were feeding, and others also have made observations which imply that the sea otter capture fishes rather readily. Fish remains appear frequently in sea otter excreta.
Important losses in sea otter no doubt occur as the result of nematode infection. $P$. decipiens is sometimes highly pathogenic in the larval stages, although the adult worms seem to have no deleterious effect upon the host. According to present knowledge, the nematodes may be divided into three groups, according to degree of pathogenicity:

1. The earliest stage found in sea otter (i.e., worms having a cephalic spike) appears to be the most pathogenic. This larval stage was always associated with intestinal perforation and seemed directly responsible for all sea otter deaths known to have resulted from nematode infection (Fig. 7).

2. Later larval stages, possessing fully developed lips, but still sexually immature, were usually found attached in closely associated aggregations in the sea otter stomach. These are considered only mildly pathogenic (Fig. 8).

3. Adult worms, not commonly found, appeared to be nonpathogenic. Nematodes in the adult stage were not observed attached to the mucosa of the stomach nor associated in any way with intestinal perforation.

Symptomatology. It was not possible to define clearly the symptoms associated with nematode infection in sea otter. Lack of diarrhea served to differentiate such animals from those suffering from the other two enteric conditions observed. Otter captured in the terminal stages of nematode infection showed depression and weakness. They often fed readily up to a few hours preceding death. Old adult otter as well as young animals were affected by Porrocaecum infections.

Since most of the life of the sea otter is spent in a marine habitat, the animals are not well adapted for extra-aquatic activities. Their abdominal muscles are relatively flaccid, and the visceral organs are not firmly supported. As a result, it would seem that the rather violent handling to which they are usually sub- 


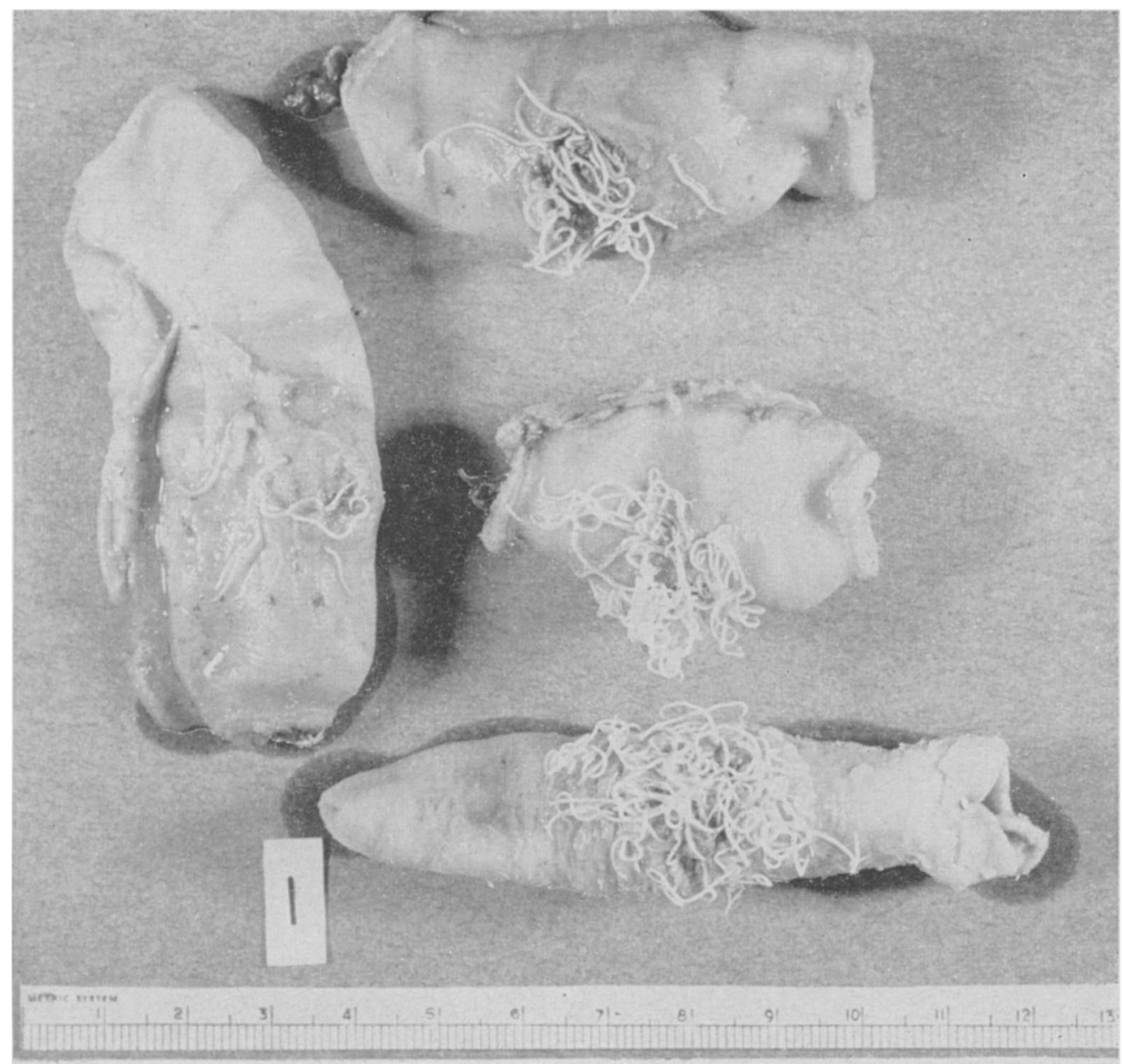

FIG. 7. Gross specimens of sea otter duodenum, showing appearance of perforations caused by Porrocacum decipiens. These nematodes are in the earliest larval stage to be observed in sea otter-i.e., possessing a cephalic pike.

jected during capture might have a detrimental effect upon otter having numerous visceral adhesions. The disruption of adhesions at time of capture might bring about an early death in captive animals.

Gross pathological changes. Since sea otter apparently have little or no subcutaneous or intra-abdominal fat deposit normally, deteriorated body condition was not readily detected. A few animals were emaciated, however.

Generalized peritonitis appeared to be the eventual cause of death in case of intestinal perforation by nematodes. Upon opening the ventral abdominal wall, numerous Porrocaecum larvae were noted usually lying free on the surface of the greater omentum, between it and the abdominal wall. The body cavity usually contained a quantity of a thin, often blood-stained, fluid. A fibro-purulent exudate coated the serous membranes, and the intestinal coils were adherent to one another. Multiple perforations of the small intestine were the rule, although sometimes but a single perforation was noted. The omentum was usually adherent to the inflamed area. In a few cases the omentum itself was directly invaded by nematode larvae, and under 


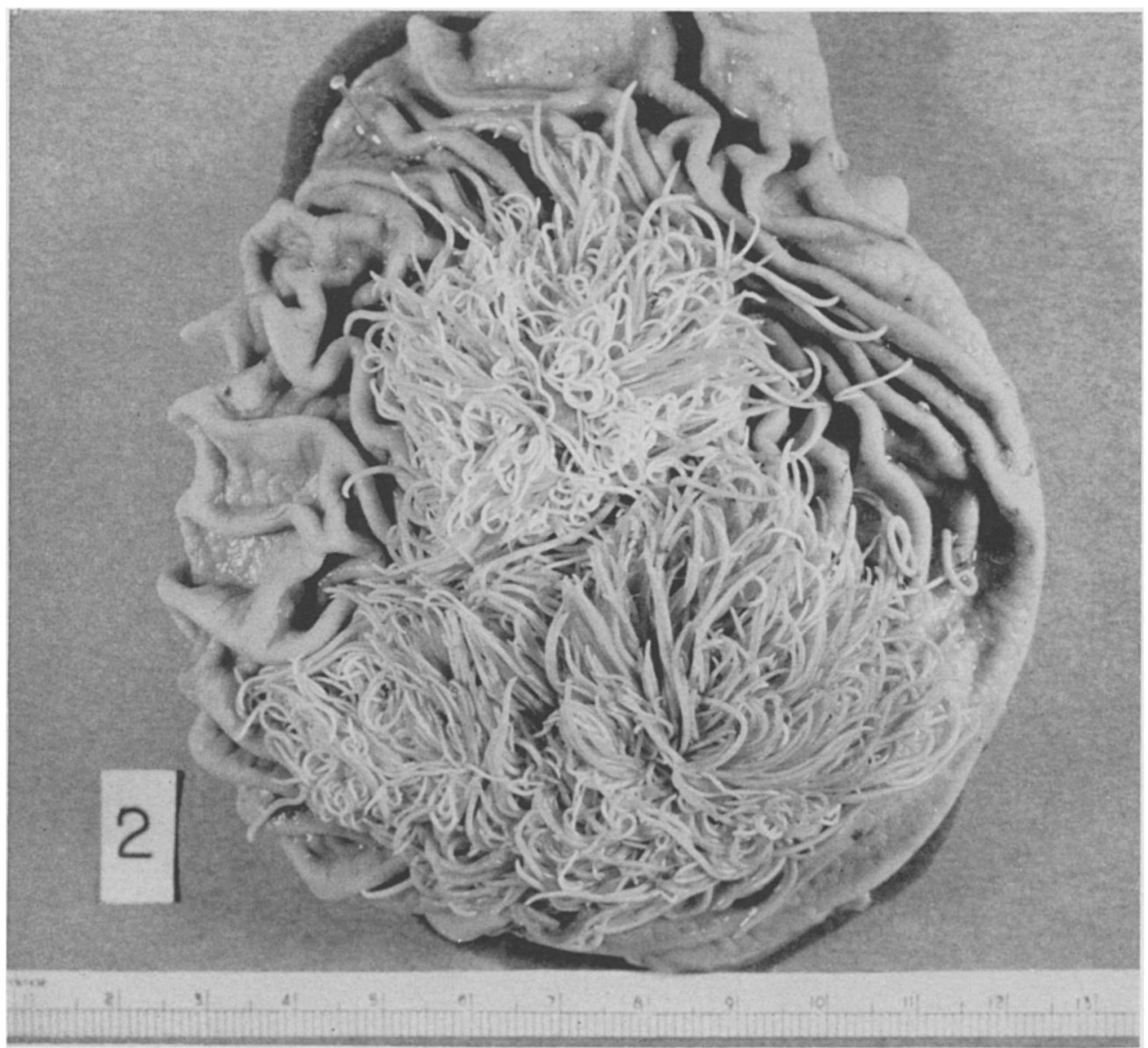

FIg. 8. Aggregations of Porrocaecum decipiens in stomach of sea otter. Two larval stages are represented. Tissue damage is slight.

such circumstances a thickening of the omentum was noted. Often there was further adherence to other organs-e.g., spleen or liver. When such was the case, an uninterrupted way was furnished along which the larvae moved; direct invasion of spleen, liver, or other organs then resulted. Fibrosis was often advanced, resulting in very firm adhesions.

Intestinal perforations were surrounded by large inflamed areas which were greatly congested, and contrasted strongly with the normal tissue. The nematodes protruded through the perforation from the lumen of the intestine, generally in large numbers (Fig. 7). Many were deeply embedded in the tissue reaction products on the omentum, or within other organs. Incising the intestine disclosed dense aggregations of nematodes attached around the site of perforation. Such firmly anchored masses of worms no doubt occluded the intestinal lumen to a significant degree.

The body of the stomach usually showed one or more dense aggregations of nematodes, the anterior ends of which were firmly embedded in the gastric mucosa. Later larval stages predominated here, as differentiated grossly by their darker color in contrast to the more translucent appearance of the earliest stage (Fig 8). There was no evidence that the stomach wall is ever perforated. 
Other organs were not characteristically affected. Any other lesions noted could be attributed to secondary effects of generalized peritonitis.

Animals with peritonitis showed a neutrophilic leukocytosis. From 26 to 43 per cent of the total leukocytes were stab cells. Eosinophiles were few or absent. From 24 to 40 per cent of the total leukocytes were lymphocytes.

Histopathological observations. Stomach. The anterior ends of the nematodes were deeply embedded in the gastric mucosa; the latter was severely eroded to the depth of the muscularis musoca in immediate area of attachment (Fig. 9). Fibrocytic proliferation was marked, and normal structure was severely altered. Cavities surrounding the nematode heads were filled with acidophilic material which probably was semifluid in the living animal. Bacilli were abundant in these cavities, particularly around the periphery of the contained substance. The nematodes penetrated usually not deeper than the muscularis mucosa, but in some cases the muscularis externa was invaded. Leukocytic infiltration was limited to cells of

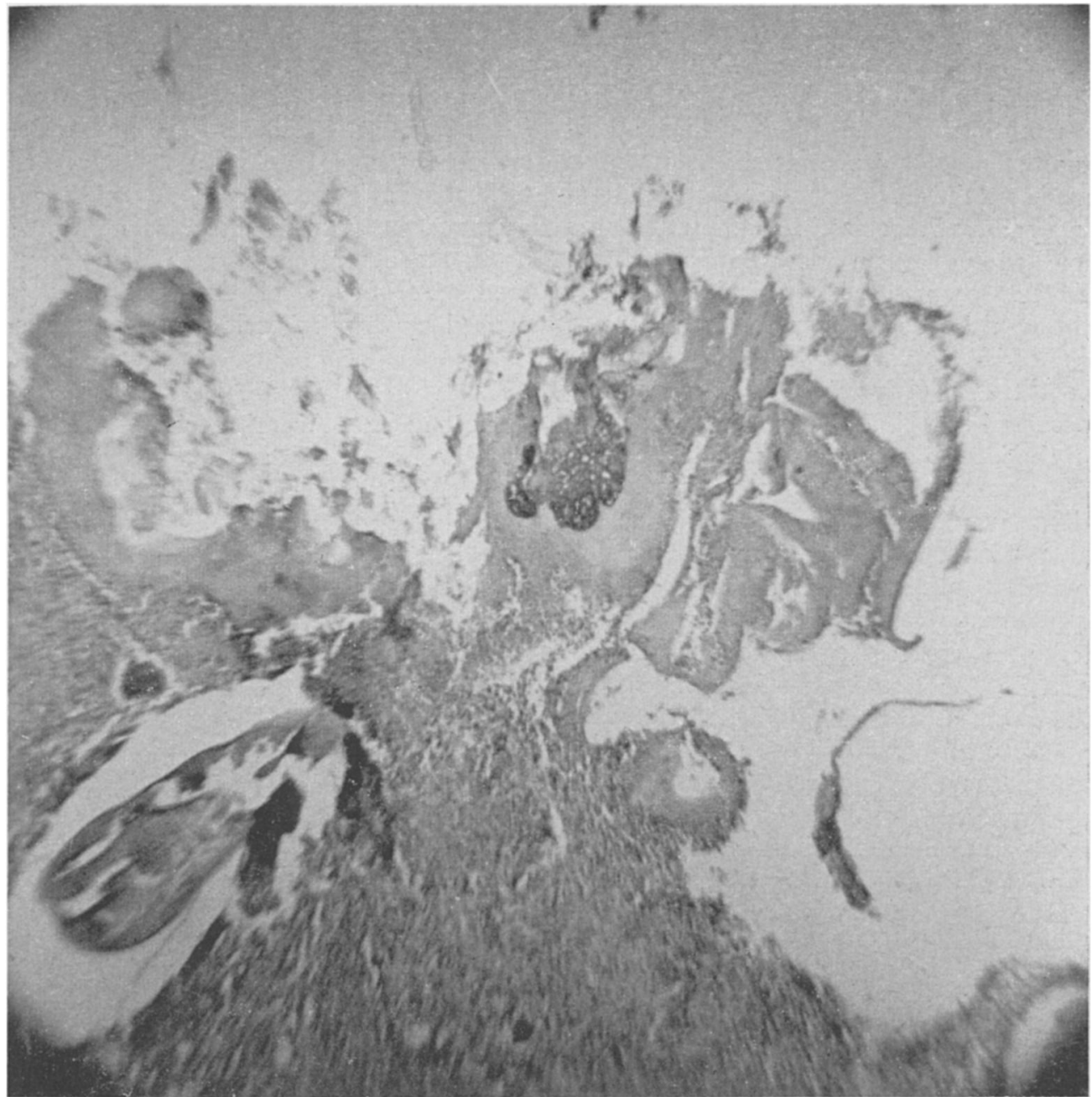

FIG. 9. Gastric mucosa of sea otter, showing injury caused by larvae of Porrocaecum decipiens. Low power. 
a mononuclear type; polymorphonuclear cells, or their precursors, were not noted. The mucosa of the areas surrounding the sites of nematode attachment was hyperemic.

Hoeppli (1932) described the pathological changes brought about by a species of Anisakis in the stomach of the walrus, Odobenus rosmarus L. Hoeppli (1927) and Hoeppli and Feng (1931) pointed out that a degree of tissue liquefaction takes place under these circumstances, and attributed this effect to the action of the oesophageal glands. Those species infecting marine mammals appear to be particularly well adapted to this type of tissue invasion.

Duodenum. The areas of intestinal perforation showed fibro-purulent peritonitis. Polymorphonuclear neutrophils made up the main component of infiltrating cells. Fibroblastic proliferation was marked in the main areas of inflammation. Several nematodes protruded directly through the openings, while others were embedded at various levels in the adjacent tissue (Fig. 10). The nematodes occurred in foci, and were never observed in the intestinal wall at any distance from the invasion center. The destruction of tissue was limited also to the immediate area surrounding this focus. The surrounding mucosa showed epithelial desquamation, but seemed otherwise unaltered. Bacteria were not conspicuous except in the fragments of debris within the perforated area. Only bacilli were noted, probably coliform organisms.

Omentum. The serous surfaces of the omentum were in part covered with a fibro-purulent exudate; however, the serosal epithelium was often intact. Fibroblastic proliferation was marked. The cellular reaction consisted mainly of polymorphonuclear leukocytes, with good numbers of lymphocytes. Nematodes in some cases were deeply embedded in inflammatory tissue; here also was evidence of liquefaction of tissue around the anterior ends of the worms.
Spleen. Splenic invasion occurred only via adherent omentum. Marked fibrosis was noted. The cellular components of the exudate consisted largely of polymorphonuclear leukocytes, although macrophages were numerous. Plasma cells were also frequently observed. Hyperemia was noted in areas surrounding the nematodes.

Other organs. Nost of the changes seen in other organs were associated with the generalized peritonitis. Amorphous casts were occasionally observed in the renal tubules.

\section{Corynosoma strumosum (Rudolphi, 1802)}

Acanthocephala were recorded from four sea otter. The common and widespread (both geographically and in regard to host-species occurrence) C. strumosum occurred in Amchitka sea otter as well as in the other marine mammals examined. A very local tissue reaction is evoked by the proboscis of the parasites.

\section{Corynosoma sp.}

Among the Acanthocephala collected on Amchitka from sea otter and from Steller's sea lion was a number of specimens which represent an undescribed species of Corynosoma. All acanthocephalan material was turned over to Dr. H. J. Van Cleave, Department of Zoology, University of Illinois, for study. This description will be published separately.

C. enhydris Afanas'ev, 1941, was described from the sea otter of the Komandorskii Islands. In the opinion of Dr. Van Cleave (personal communication), the description of $C$. enhydris is inadequate. Until additional material becomes available for study, its status must remain somewhat indefinite. On the basis of proboscis hook number, however, it was determined that it is not identical with $C$. strumosum nor the undescribed species of Corynosoma mentioned above. 


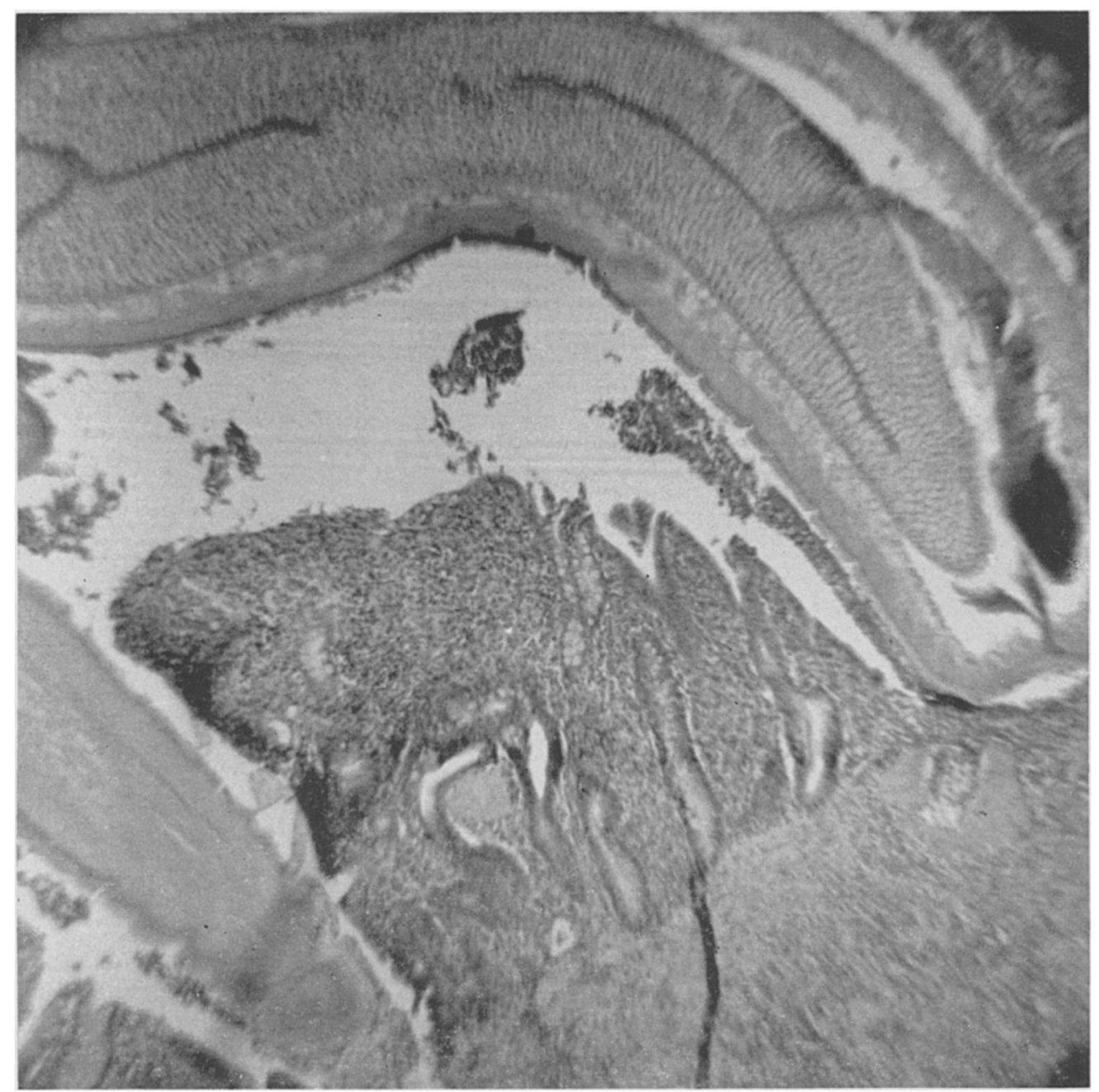

FIg. 10. Small intestine of sea otter, near perforation, showing invasion by $P$. decipiens larvae. Low power.

\section{Idiopathic enteritis}

Enteritis was the predominant disorder affecting sea otter during the time of this investigation. Ordinarily, it was attributable to $M$. pirum infection, but in a few instances a fatal enteritis without the concomitant termatode infection was noted.

In the absence of any recognized etiologic agent, it can only be assumed that some other factor, so far undetected, is involved. It must be emphasized also that the effect of some other disease-producing factor may be in every case superimposed upon the $M$. pirum infection, although the writer is of the opinion that $M$. pirum alone is an important pathogen. Despite these complications, this condition for the present time may be treated as a separate entity.

Symptomatology. In the wild state, the morbid sea otter were sluggish and relatively inactive. They seemed to frequent the beaches, where their semi-fluid, dark-colored excreta contrasted strongly with those of the normal animals. The onset of the disease was acute, and there was little physical deterioration. Greatly elevated temperatures were not recorded. 
The animals continued to feed readily up to a few hours of death.

Gross pathological changes. A severe hyperemia of the small intestine was characteristic. Intussusception had occurred in one case, with blood stasis. As mentioned above, in reference to $M$. pirum, a tightly adherent layer of fibrinous exudate was often noted. Gastritis was ordinarily associated with the enteritis, but it was relatively mild. Petechiae were noted occasionally on the liver, and in some cases the kidneys were hyperemic, particularly in the cortical region.

Histopathological observations. Severe hyperemia of the villi was characteristic, with engorgement of the central vein. Peripheral hyperemia of the villi was evident (Fig. 11). The lamina propria was hyperemic, as was the muscularis externa to a lesser degree. Massive desquamation of the mucosal epithelium was characteristic, so that an important component of the exudate was mucosal fragments in which cellular identity was still preserved. Such fragments were abundant between the congested villi and the amorphous debris covering the mucosal surface. Leukocytic infiltration was lacking. Bacteria were not observed in the zone of inflammation.

The gastric mucosa was hyperemic, but epithelial desquamation was not observed. Renal hyperemia was observed in a few cases, with the congestion particularly marked in the cortex of the lobes. (The otter kidney is superficially lobed.) The glomeruli were normal.

\section{Bacteriological Studies}

An effort was made to isolate any bacteria which might have been involved in sea otter enteritis. Animals near death were killed so that uncontaminated material in most favorable condition could be obtained. Inoculations were taken from all appropriate organs, and from the gastro-intestinal tract. The following media were inoculated in the field: Kligler iron agar, urea agar, plain agar, blood agar, and beef infusion broth. After incubation in the field, during which time good growth in some cases was obtained, the cultures were returned to the laboratory for study.

Non-lactose fermenting organisms as well as representative lactose fermenters were inoculated on Kligler iron agar. After incubation for 24 hours, acid and gas formation throughout the medium were considered evidence of coliform bacteria. Slants having typical acid formation with or without gas were checked with Salmonella and Shigella antisera. Organisms showing a positive reaction with the antisera were inoculated into suitable media.

Results. Coliform organisms predominated. In a few cases, Gram-negative anaerogenic bacilli showing some of the antigenic components of the Shigella group were isolated. This organism did not give the biochemical reactions of Shigella, however, and was possibly a paracolon. Serologically, negative results were obtained in Polysalmonella typing attempts. Shigella typing results were not significant.

If this work can be pursued further, additional investigation of the possible role of bacteria should be made. Animal inoculations and other appropriate tests should be undertaken. The possibility of involvement of other microorganisms should not be overlooked.

\section{Discussion}

With the exception of Microphallus pirum, whose status is not well understood, all the helminths parasitic in the sea otter have long been known as parasites of other marine mammals. Of the helminth species discussed in the present paper, no effect to the host is recognized when Phocitrema fusiforme and Pricetrema zalophi are involved. Pyramicocephalus phocarum, probably a rare and unimportant parasite of the sea otter, produces localized lesions in the gastric mucosa of the bearded seal, the only host 


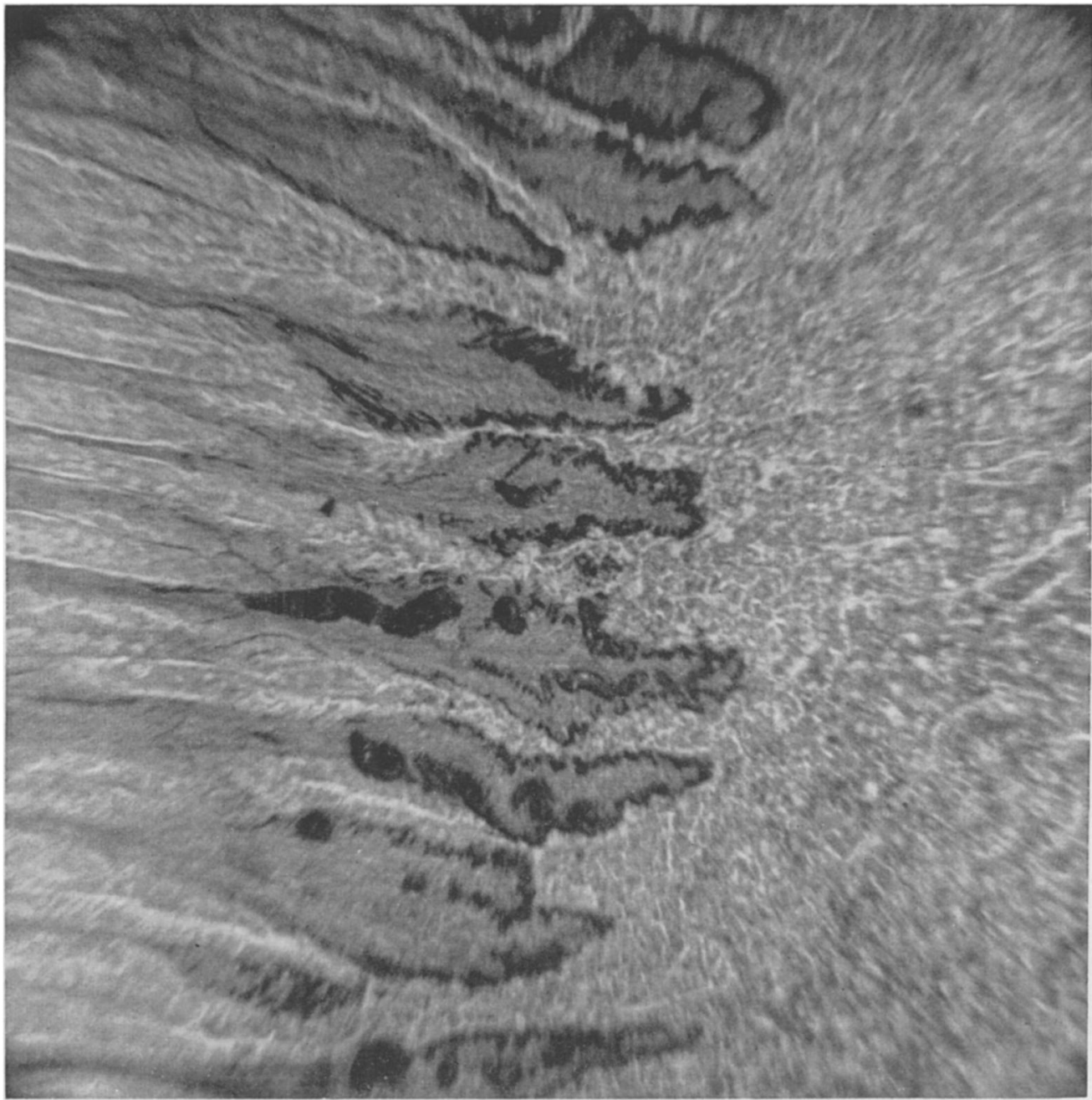

FIG. 11. Sea otter enteritis. Hyperemia of the villi. Low power.

species in which the writer has regularly observed it. The two species of Corynosoma reported here are unimportant parasites insofar as the sea otter is concerned. It is conceivable that the presence of great numbers of Corynosoma spp. might result in enough inflammation and fibrosis of the host intestine to bring about a serious effect. Generally speaking, however, the closely localized tissue reaction caused by these Acanthocephala is inadequate in amount to affect the host, at least in any recognizable manner.

Orthosplanchnus fraterculus parasitizes certain seals about as frequently as it does the sea otter. The writer has not observed in the gall bladder of the bearded seal (from which O. fraterculus was collected along the Arctic Coast of Alaska) the pathological changes regularly noted in the sea otter gall bladder. This trematode has, then, a commensal relationship with the bearded seal.

Anisakine nematodes commonly parasitize pinnipeds, and they are very abundant in Alaskan phocids [viz., bearded seal; ringed seal (P. hispida Schreber) ; harbor seal]. Among otariids, the writer has had opportunity to obtain material only from Steller's sea lion. The report 
by Stiles and Hassall (1899), however, gives detailed information on the occurrence of such nematodes in the Pribilof fur seal. Walrus infected by nematodes have been relatively few among those examined by the writer.

Porrocaecum decipiens, among others, is often seen in colony-like aggregations in the stomach of pinnipeds. A similar condition is regularly observed in the sea otter, as mentioned above (Fig. 8). In any case, the effect on the host does not appear to be important, since the amount of damage done the gastric mucosa is relatively slight.

The larval stages of $P$. decipiens and related species do not, to the writer's knowledge, invade the intestinal wall of the pinniped host. Intestinal perforation and extensive migrations in the viscera of sea otter appear to be peculiar of larval behavior in this host species alone.

The pinnipeds comprise an ancient group of highly specialized marine mammals. It is recognized that they share a common derivation with land carnivores, but the sea otter, a mustelid, cannot be considered related closely to them. It appears to the writer that the helminths considered herein, with the exception of $M$. pirum, must be regarded as having become adapted over a long period of time to a parasitic existence in pinnipeds. The sea otter, through its feeding habits, is subject to infection by helminths adapted to existence in another group of mammals phylogenetically not closely related. The attendant immuno-physiological differences may be relatively great, and unusual behavior of the helminth parasites may result.

The interrelationships of $M$. pirum are not well understood. If the hermit crab should prove to be the only intermediatehost species, the sea otter may be the only marine mammal frequently exposed to infection. Deep-water crab species should be investigated. The true role of $M$. pirum in sea otter mortality can only be elucidated through experimental work.
With Schiller's finding the metacercarial stage of $M$. pirum, the establishment of experimental laboratory infections has become possible. Rausch (1947) showed that another species, $M$. opacus (Ward, 1894), is able to infect a variety of host species. A similar lack of specificity may exist in the case of $M$. pirum. The possibility that it may infect birds has not yet been eliminated. A better concept of the significance of sea otter enteritis will also come about through controlled infection experiments with $M$. pirum.

Remedial measures for the reduction of losses in Amchitka sea otter, if such are feasible, cannot be established without further investigative work. It is entirely possible that the sea otter populations here have exceeded the carrying capacity of the habitat. The present degree of consumption of hermit crabs and fishes, both of which transmit pathogenic parasites, may be an unnatural one, but one enforced through reduction of more suitable food species. Comparable studies on other islands are badly needed to determine these relationships. The significance of the unusual sex ratio among morbid otter also needs clarification in regard to that of the population as a whole.

Mr. Howard A. Powers, U. S. Geological Survey, Denver, Colorado, spent several months in 1951 on the Rat Islands, and during this time kept careful record of his observations on sea otter. According to Mr. Powers (personal communication), the relative abundance of sea urchins on the islands with fewer otter was noteworthy. Observations on the islands of Kiska, Little Kiska, and Rat Island enabled him to estimate that otter on these islands were only from 10 to 25 per cent as abundant as on Amchitka. Comparable impressions regarding the sea otter-sea urchin relationship have been expressed by others, but lack of adequate information for earlier times prevents any conclusion. This nevertheless emphasizes the need for adequate 
investigation of the entire problem in the Rat Islands region.

If it is true, as stated by BarabashNikiforov (1935, p. 256) that the yearly increment of a sea otter population may be relatively low (only 7 per cent on Mednii Island), it is obvious that heavy losses, as suffered by the Amchitka animals in 1951, cannot be tolerated. It is worthy of mention that Mr. Powers (see above) observed only two to three dead animals on each of the islands visited by him. All appeared to have died during the winter of 1951 . He made no observations on the islands of Segula and Semisopochnoi, which probably also have sea otter.

It is possible, in view of present knowledge, that the total protection afforded the sea otter in recent years (since July 7,1911 ) has reached the point on Amchitka where its purpose is defeated. It does not seem unreasonable to suggest that an effort to reduce artificially the Amchitka sea otter population might be in order. The operation should be selfsustaining, in view of the relatively high value of sea otter pelts. In any event, some provision should be made to salvage the pelts of animals dying from disease, since their value is considerable, and apparently not much lessened through the disorders affecting the animals.

Effective redistribution of sea otter to other suitable habitat probably would be the most effective means to bring the species back to a numerical abundance adequate to permit some annual economic utilization. In the writer's opinion, the use of aircraft would permit the most effective removal of otter to new localities, particularly since the time spent in captivity would be greatly reduced. If the obstacles can be overcome, the potential value of the sea otter is very high.

Any attempt on Amchitka to reduce or exterminate animal species which harbor the same parasite species as the sea otter should not be considered. The sea otterhelminth relationships discussed in this paper are self-perpetuating. Destruction of seals and sea lions would not affect in any conceivable way the extent of losses among the sea otter.

\section{REFERENCES}

Afanas'ev, V. P. 1941. Parazitofauna promyslovykh mlekopitaiushchikh Komandorskikh Ostrovov. Uchenie Zapiski, Seriia biologicheskikh Nauk, 18: 93-117.

Africa, C. M., E. Y. Garcia, and W. de Leon. 1935. Intestinal heterophyidiasis with cardiac involvement; a contribution to the etiology of heart failure. Abstract. J. Phi1. Isl. Med. Assoc., 15 : 358-361.

Barabash-Nikiforov, I. 1935. The sea otters of the Commander Islands. J. Mammal., 16: 255-261.

Bobrinskii, N. A., B. A. Kuznetsov, and A. P. Kuziakin. 1944. Opredelitel' mlekopitaiushchikh SSSR. Moscow, $440 \mathrm{pp}$.

Cable, R. M. and M. L. Kuns. 1951. The trematode family Microphallidae with the description of Carneophallus trilobatus gen. et sp. nov., from Mexico. J. Parasit., 37 : 507-514.

Cordy, D. R. and J. R. Gorham. 1950. The pathology and etiology of salmon disease in the dog and fox. Amer. J. Path., 26: 617-637.

Hoeppli, R. 1927. Ueber Beziehungen zwischen dem biologischen Verhalten parasitischer Nematoden und histologischen Reaktionen des Wirbeltierkörpers. Beihefte zum Arch. f. Schiffs u. Tropen. Hyg., 31: 207-290.

. 1932. Tissue reactions due to parasites. Far East. Assoc. Trop. Med. 8th Congr., 2: 173-183.

, and L. C. Feng. 1931. On the action of esophageal glands of parasitic nematodes. Experiments with Spirocerca sanguinolenta from the dog and Physaloptera clausa from the hedgehog. Nat. Med. J. China, 17 : 589-598.

Johnston, T. H. and Patricia M. Mawson. 1945. Parasitic nematodes. In B.A.N.Z. Antarctic Research Expedition 1929-1931. Reports-Ser. B. Vol. 5, Pt. 2: 77-159.

Jones, R. D. 1951. Present status of the sea otter in Alaska. Trans. 16th N. A. Wildlife Conf.: 376-382.

Murie, O. J. 1940. Notes on the sea otter. J. Mamma1., 21: 119-131.

- V. B. Scheffer, J. H. Steenis, and H. D. Gray. Report on biological investigations in Aleutian Islands, Alaska. May 4-September 21, 1937. (Manuscript.) 
Rausch, R. 1947. Some observations on the host relationships of Microphallus opacus (Ward, 1894) (Trematoda: Microphallidae). Trans. Amer. Micr. Soc., 66: 59-63. , and Betty Locker. 1951. Studies on the helminth fauna of Alaska. II. On some helminths parasitic in the sea otter, Enhydra lutris (L). Proc. Helm. Soc. Wash., 18 : 77-81.

Schiller, E. L. 1952. Studies on the helminth fauna of Alaska. V. Notes on Adak rats (Rattus norvegicus Berkenhout) with special reference to helminth parasites. I. Mammal., 33 : 38-49.

1953. Studies on the helminth fauna of Alaska. XVII. Notes on the intermediate stages of some helminth parasites of the sea otter. (Manuscript.)

Steller, G. W. 1749. De Bestiis marinis.
(Trans1.) In D. S. Jordan. The fur seals and fur seal islands of the North Pacific Ocean. Rept. of fur-seal Invest. 18961897, Part 3. 1899. U. S. Govt. Ptg. Off., Washington, pp. 179-218.

Stiles, Ch. W. and A. Hassall. 1899. Internal parasites of the fur seal. In $D$. S. Jordan. The fur seals and fur-seal islands of the North Pacific Ocean. Rept. of furseal Invest. 1896-1897, Part 3. 1899. U. S. Govt. Ptg. Off., Washington, pp. 99-177.

Stunkard, H. W. 1951. Observations on the morphology and life-history of Microphallus limuli n. sp. (Trematoda: Microphallidae). Biol. Bull., 101: 307-318.

Willey, C. H. and H. W. Stunkard. 1942. Studies on pathology and resistance in terns and dogs infected with the heterophyid trematode, Cryptocotyle lingua. Trans. Amer. Micr. Soc., 